\title{
Large variation in the association between seasonal antibiotic use and resistance across multiple bacterial species and antibiotic classes
}

\author{
Daphne S. Sun ${ }^{1}$, Stephen M. Kissler ${ }^{1}$, Sanjat Kanjilal2,3,4,5, Scott W. Olesen ${ }^{1}$, Marc Lipsitch ${ }^{1,6}$, \\ Yonatan H. Grad ${ }^{1,3}$
}

1. Department of Immunology and Infectious Diseases, Harvard T.H. Chan School of Public Health, Boston, MA, USA

2. Department of Population Medicine, Harvard Medical School and Harvard Pilgrim Health Care Institute, Boston, MA, USA

3. Division of Infectious Diseases, Department of Medicine, Brigham and Women's Hospital, Harvard Medical School, Boston, MA, USA

4. Department of Pathology, Brigham and Women's Hospital, Boston, MA, USA

5. Division of Infectious Disease, Massachusetts General Hospital, Boston, MA, USA

6. Center for Communicable Disease Dynamics, Department of Epidemiology, Harvard Chan School of Public Health, Boston, MA, USA

Correspondence: Yonatan H. Grad (ygrad@hsph.harvard.edu)

\section{Abstract}

Understanding how antibiotic use drives resistance is crucial for guiding effective strategies to limit the spread of resistance, but the variation in the use-resistance relationship across pathogens and antibiotics remains unclear. Here, we applied sinusoidal models to evaluate the seasonal use-resistance relationship across 3 species and 5 antibiotic classes in Boston, Massachusetts. Use of all 5 classes and resistance in 10 of 15 species-antibiotic combinations showed significant amplitudes of seasonality. However, while seasonal peaks in use varied by class, resistance in all 10 species-antibiotic combinations peaked in the winter and spring. The correlations between seasonal use and resistance thus varied widely, with resistance to all antibiotic classes being most positively correlated with use of the winter-peaking classes (penicillins and macrolides). These findings suggest that in some cases the simple model of use selecting for resistance is inadequate and stewardship strategies will not be equally effective across all species and antibiotics. 
medRxiv preprint doi: https://doi.org/10.1101/2020.12.21.20248670; this version posted December 22, 2020. The copyright holder for this

preprint (which was not certified by peer review) is the author/funder, who has granted medRxiv a license to display the preprint in perpetuity.

It is made available under a CC-BY-NC-ND 4.0 International license .

\section{Introduction}

34 Antibiotic resistance is a growing threat to society, with important public health ${ }^{1}$ and economic consequences $^{2}$. Antibiotic use is considered a primary driver of resistance not only in the pathogen targeted by the antibiotic but also in host-associated bacteria subject to 'bystander selection'3. As such, the effort to reduce antibiotic use is an important strategy for broadly limiting the spread of resistance. However, such interventions may not be equally effective across all antibiotics and bacterial pathogens and will likely depend on the strength of the relationship between use and resistance in each case. Therefore, we need to expand our understanding of these use-resistance relationships and identify factors that influence their

42 strength.

The reported associations between antibiotic use and resistance have varied widely across previous ecological studies on the scale of European countries and US states ${ }^{4-10}$. Several reports found strong use-resistance associations in a small number of bacterial pathogens

47 (primarily Streptococcus pneumoniae and Escherichia coli) and antibiotics (macrolides, $\beta$ -

48 lactams, and quinolones) ${ }^{4-8}$. However, a recent study that analyzed 72 species-antibiotic

49 combinations found that the correlation between use and resistance, while generally positive,

50 covered a large range and often appeared weaker than might be expected based on earlier

51 reports $^{9}$. In some cases, the difficulty in detecting associations may be attributed to several

52 challenges of using annual geographic data to infer use-resistance relationships ${ }^{11}$. For example,

53 the similar levels of use between regions and the existence of possibly strong 'spillover' effects ${ }^{12}$

54 - where use in one region affects resistance in surrounding regions due to transmission

55 between populations - can limit the power to detect associations. Geographic analyses are also

56 limited by confounding from comparing between populations, which arises when there are

57 variations between regions in factors other than antibiotic use, such as population 
medRxiv preprint doi: https://doi.org/10.1101/2020.12.21.20248670; this version posted December 22, 2020. The copyright holder for this

preprint (which was not certified by peer review) is the author/funder, who has granted medRxiv a license to display the preprint in perpetuity.

It is made available under a CC-BY-NC-ND 4.0 International license .

demographics, healthcare infrastructure, and dominant strains of circulating pathogens, that can also contribute to differing levels of resistance.

Seasonal variations in antibiotic use and resistance within a single region offer another approach to studying the use-resistance relationship ${ }^{13-16}$, with several advantages. First, seasonality studies enable assessment within a single population, thus minimizing confounding from comparing between populations or along secular trends ${ }^{11}$. Thus seasonality studies may better approximate the causal use-resistance relationship than geographic analyses. Second, the magnitude of seasonal variations in use often exceeds the variation in use across years or geographic regions ${ }^{16,17}$, which can provide seasonality studies with greater power to detect associations between use and resistance.

Previous studies found that the antibiotic use-resistance relationship is detectable on a seasonal timescale, with positive associations in Streptococcus pneumoniae ${ }^{13}$, Escherichia coli ${ }^{14,15}$, Staphylococcus aureus ${ }^{14}$, and Neisseria gonorrhoeae ${ }^{16}$. However, these studies focused on the most highly prescribed antibiotic classes, such as $\beta$-lactams and macrolides, for which use peaks in the wintertime ${ }^{17}$. Further, many of the species-antibiotic combinations studied were the same combinations that showed among the strongest use-resistance correlations in earlier geographic studies ${ }^{4,9}$. Therefore, it remains unclear whether the strength of the seasonal useresistance relationship extends across a broader range of species and antibiotics, particularly for antibiotics with different seasonal patterns and lower rates of use.

In this study, we evaluated the extent to which seasonal variations in antibiotic use correlate with variations in resistance across multiple antibiotic classes and bacterial species in Boston, Massachusetts. Our analysis included 5 antibiotic classes-penicillins, macrolides, quinolones, nitrofurans, and tetracyclines-which represent a range of prescribing rates and seasonal 
medRxiv preprint doi: https://doi.org/10.1101/2020.12.21.20248670; this version posted December 22, 2020. The copyright holder for this preprint (which was not certified by peer review) is the author/funder, who has granted medRxiv a license to display the preprint in perpetuity.

It is made available under a CC-BY-NC-ND 4.0 International license .

84 patterns of use ${ }^{13,14,16,17}$ and 3 bacterial species-Staphylococcus aureus, Escherichia coli, and

85

86

87

88

89

90

91

92

94

95

96

97

Klebsiella pneumoniae — which represent skin/nasal and gut colonizing bacteria ${ }^{18,19}$ that cause a diversity of infections types and are subject to strong bystander selection ${ }^{3}$. To conduct our study, we compared seasonal antibiotic use data for Boston residents, obtained from a centralized state-wide insurance claims database, with resistance data from two major Bostonarea hospitals. Given the near-universal health insurance coverage in the state ${ }^{20}$, this analysis provided a unique opportunity to characterize the antibiotic use-resistance relationship in a dataset that captures close to the full picture of antibiotic use in a population. Overall, this work contributes to our understanding of the use-resistance landscape and helps inform the design of effective stewardship policies to reduce the overall burden of resistance.

\section{Results}

\section{Seasonality in antibiotic use varies across classes}

The five antibiotic classes included in this study, which accounted for $74 \%$ of the total outpatient antibiotic claims in this dataset, each displayed measurable seasonal patterns of use (Figure 1A). Penicillins and macrolides were most frequently prescribed, with year-round averages of 14.6 and 12.4 monthly claims per 1000 people, respectively. Quinolones, tetracyclines, and nitrofurans were prescribed with year-round averages of 5.3, 3.1, and 1.6 monthly claims per 1000 people, respectively.

Penicillins had the greatest magnitude change in prescribing rate across seasons, with an amplitude of 3.3 additional claims per 1000 people above the yearly average at its peak (95\% $\mathrm{Cl}, 2.7$ to 4.0 ). This was followed by macrolides (amplitude, $2.2 ; 95 \% \mathrm{Cl}, 1.6$ to 2.7 ), quinolones (amplitude, $0.26 ; 95 \% \mathrm{Cl}, 0.12$ to 0.40 ), nitrofurans (amplitude, $0.14 ; 95 \% \mathrm{Cl}, 0.07$ to 0.22 ), and tetracyclines use (amplitude, $0.12 ; 95 \% \mathrm{Cl}, 0.04$ to 0.20 ) (Figure 1B). 
medRxiv preprint doi: https://doi.org/10.1101/2020.12.21.20248670; this version posted December 22, 2020. The copyright holder for this preprint (which was not certified by peer review) is the author/funder, who has granted medRxiv a license to display the preprint in perpetuity.

It is made available under a CC-BY-NC-ND 4.0 International license .

110 The timing of peak prescribing varied by antibiotic class (Figure 1B). Macrolide and penicillin

111 use peaked in the winter, around late January (phase, 1.8 months; $95 \% \mathrm{Cl}, 1.3$ to 2.2; note that

112 phase is indexed to 1.0 representing January 1st) and mid-February (phase, 2.3 months; $95 \%$

$113 \mathrm{Cl}, 1.9$ to 2.6), respectively. Tetracycline and nitrofuran use peaked in the summer, around late

114 June (phase, 6.7 months; $95 \% \mathrm{Cl}, 4.8$ to 8.5) and late August (phase, 8.7 months; $95 \% \mathrm{Cl}, 8.0$

115 to 9.4), respectively. Finally, quinolone use peaked twice a year in late December and late June

116 (phase, 0.9 months; $95 \% \mathrm{Cl}, 0.3$ to 1.4 ).

117

118

119

120

121

122

123

124

125

126

127

128

129

130

131

132

133

134

135

\section{Seasonality in antibiotic resistance is prevalent across species and antibiotic classes}

Resistance was seasonal for 10 out of 15 species-antibiotic combinations (Figure 2, Figure S1, Figure S2), with significant amplitudes of seasonality (FDR $<0.05)$ ranging from 0.012 to 0.064 doubling dilutions (Figure 3). Ciprofloxacin resistance and nitrofurantoin resistance were seasonal in all three species with a 12-month period (Figure 2, Figure S1, Figure S2).

Resistance to erythromycin in $S$. aureus was also seasonal with a 12-month period (amplitude, $0.049 ; 95 \% \mathrm{Cl}, 0.013$ to 0.086$)$. Conversely, tetracycline resistance was not seasonal in any of the three species (Figure 2, Figure S1, Figure S2). Seasonality of resistance to penicillin class antibiotics was variable across species. Oxacillin resistance in $S$. aureus was seasonal with a 12-month period (amplitude, $0.033 ; 95 \% \mathrm{Cl}, 0.010$ to 0.055 ), while both penicillin resistance in S. aureus (amplitude, $0.013 ; 95 \% \mathrm{Cl},-0.008$ to 0.034 ) and amoxicillin/clavulanate resistance in K. pneumoniae (amplitude, $0.032 ; 95 \% \mathrm{Cl},-0.0003$ to 0.064 ) did not show evidence of seasonality. Ampicillin and amoxicillin/clavulanate resistance in E. coli were the only speciesantibiotic combinations that showed a 6-month period in seasonality, with amplitudes of 0.033 (95\% Cl, 0.018 to 0.047$)$ and $0.012(95 \% \mathrm{Cl}, 0.001$ to 0.022$)$, respectively. Of note, despite having a slightly worse fit, the 12-month period model of ampicillin resistance in $E$. coli also appeared seasonal (amplitude, 0.040; 95\% CI, 0.018 to 0.061) (Figure S3). 
medRxiv preprint doi: https://doi.org/10.1101/2020.12.21.20248670; this version posted December 22, 2020. The copyright holder for this preprint (which was not certified by peer review) is the author/funder, who has granted medRxiv a license to display the preprint in perpetuity.

It is made available under a CC-BY-NC-ND 4.0 International license .

136

137

138

139

140

141

142

143

144

145

146

147

148

149

150

151

152

153

154

155

156

157

158

159

160

161

Resistance peaked in the winter-spring months in all 10 seasonal species-antibiotic combinations, with peaks ranging from early December to mid-April (Figure 4). Comparing across species, resistance in E. coli (median phase, 3.0; IQR, 0.9) tended to peak slightly later in the year than resistance in $S$. aureus (median phase, 1.7; IQR, 0.6) and K. pneumoniae (median phase, 1.1; IQR, 1.1). Peak resistance to macrolides and penicillins in $S$. aureus and the first peak in resistance to penicillins in E. coli occurred around the same time of year as peak use of macrolides and penicillins. However, resistance to penicillins in E. coli also peaked a second time during the year in late August and October, though use did not. In addition, resistance to nitrofurans in all 3 species peaked at the opposite time of year from its use, between 3.3 to 5.8 months after peak nitrofuran use. Finally, resistance to quinolones in all 3 species peaked once a year about 1.0 to 2.3 months after the first peak in quinolone use.

\section{Seasonal resistance is positively correlated with use of winter-peaking antibiotic classes} Spearman correlation coefficients between use-resistance antibiotic pairs across all species ranged from -0.76 to 0.94 (Figure 5). Resistance to every antibiotic, regardless of class, in all three species was most positively correlated with use of winter-peaking classes, penicillins and macrolides (median Spearman's $\rho, 0.68 ;$ IQR, 0.52). Resistance to most antibiotics also showed a negative correlation with use of summer-peaking classes, tetracyclines and nitrofurans (median Spearman's $\rho,-0.46$; IQR, 0.42). Finally, resistance was not significantly correlated with use of quinolones, which peaked twice a year, for any antibiotic in any species (median Spearman's $\rho,-0.28 ;$ IQR, 0.26).

\section{Discussion}

Under a simple model in which antibiotic use drives resistance, seasonal variation in antibiotic consumption is expected to be associated with variation in population-level resistance that is in phase with or lagged up to a quarter period behind use ${ }^{21}$. Findings from previous seasonality 
medRxiv preprint doi: https://doi.org/10.1101/2020.12.21.20248670; this version posted December 22, 2020. The copyright holder for this preprint (which was not certified by peer review) is the author/funder, who has granted medRxiv a license to display the preprint in perpetuity.

It is made available under a CC-BY-NC-ND 4.0 International license .

162

163

164

165

166

167

168

169

170

171

172

173

174

175

176

177

178

179

180

181

182

183

184

185

186

187

studies have been largely consistent with this model, where use of winter-peaking antibiotics were associated with winter to spring peaks in resistance ${ }^{13-16}$. However, by including antibiotic classes with different seasonal peaks in use, we found that resistance to all antibiotics still peaked in the winter or spring, resulting in a large variation in correlations between use and resistance of the same antibiotic class. Resistance to all antibiotics best correlated with use of winter-peaking antibiotics, suggesting the need for other factors in models of the relationship between use and resistance.

The observed pattern for penicillins and macrolides_-peak wintertime use followed by peaks in resistance in late winter to spring — was mostly consistent with previous findings ${ }^{13,14,16}$ and with some theoretical predictions from models in which use drives resistance ${ }^{21}$. In $S$. aureus, use and resistance to oxacillin and erythromycin peaked in the winter, consistent with a previous seasonality study that compared macrolide use and resistance in methicillin-resistant $S$. aureus $(\mathrm{MRSA})^{14}$, as well as findings in other species-antibiotic combinations that have shown winter peaks in use and resistance with little to no $\operatorname{lag}^{13-15}$. In E. coli, the first peaks in ampicillin and amoxicillin/clavulanate resistance occurred in the winter and spring, respectively, about 0.5 to 2.5 months after the peak in penicillins use. A several month lag between use and resistance has also been previously reported in $E$. colit ${ }^{14}$ and $N$. gonorrhoeae ${ }^{9}$. Resistance to penicillins in E. coli also showed a second peak in resistance 6 months later, in the absence of a second peak in use, a finding that has not been previously reported. However, we note that a 12-month period model for ampicillin resistance in E. coli also met our criterion for seasonality and showed a single winter peak in resistance, which is more consistent with previous findings in $E$. coli ${ }^{14,15}$.

Antibiotic classes with different seasonal patterns of use, such as nitrofurans and quinolones, showed seasonal patterns of resistance that could not readily be explained based on their patterns of use. Nitrofurans, which are almost exclusively used to treat urinary tract infections 
medRxiv preprint doi: https://doi.org/10.1101/2020.12.21.20248670; this version posted December 22, 2020. The copyright holder for this preprint (which was not certified by peer review) is the author/funder, who has granted medRxiv a license to display the preprint in perpetuity.

It is made available under a CC-BY-NC-ND 4.0 International license .

$188(\mathrm{UTIs})^{22}$, showed summer peaks in use during the same season as peak UTI incidence ${ }^{23-26}$.

189 Quinolones, which are used to treat both respiratory infections and $\mathrm{UTIs}^{27}$, showed both winter

190 and summer peaks in use. However, resistance to nitrofurans and quinolones in all 3 species

191 showed only one peak in the winter or early spring. This result for quinolone resistance is

192 consistent with a previous finding in $E$. colit ${ }^{14}$, which showed a single winter peak in quinolone

193 use followed by a winter peak in resistance.

194

195 Several species-antibiotic combinations did not show seasonality in resistance. In each case,

196 this may be due to a lack of association between use and resistance, a lack of strong seasonal

197 variation in use of some antibiotic classes, or other factors, such as a signal too small to be

198 identified in our dataset. The lack of seasonality in $S$. aureus resistance to penicillin may be

199 explained by the already high prevalence of penicillin resistance in S. aureus ${ }^{28}(83 \%$ in this

200 dataset, Table S3), which may limit observable selection for resistance from increased

201 wintertime use of penicillins. For K. pneumoniae resistance to amoxicillin-clavulanate, additional

202 data may narrow the confidence intervals around the estimated amplitude of seasonality $(0.032$;

$20395 \% \mathrm{Cl}-0.0003,0.064)$. The absence of observed seasonality in tetracycline resistance in all 3

204 species may be explained by the lack of a strong seasonal variation in tetracycline use, as

205 tetracyclines showed the lowest amplitude of seasonal use among antibiotic classes (Figure 1).

206 This finding is also consistent with a previous study that found no significant correlation between

207 tetracycline use and resistance in E. colit .

208

209 Our finding that resistance to all antibiotics most correlated with use of winter-peaking antibiotic

210 classes suggests that the simple model in which use of a given antibiotic independently selects

211 for resistance is insufficient to explain the full seasonal use-resistance landscape. At least two

212 additional factors may contribute to this result. First, resistance to one antibiotic could be

213 indirectly selected for by increased wintertime use of a second antibiotic in bacteria that are co- 
medRxiv preprint doi: https://doi.org/10.1101/2020.12.21.20248670; this version posted December 22, 2020. The copyright holder for this preprint (which was not certified by peer review) is the author/funder, who has granted medRxiv a license to display the preprint in perpetuity.

It is made available under a CC-BY-NC-ND 4.0 International license .

214 resistant to both antibiotics. This is supported by evidence that co-resistance is common across

215 many bacterial species ${ }^{29}$. We might expect that selection by use of pencillins and macrolides

216 dominates over selection by other antibiotics because they are prescribed at substantially higher

217 rates and show greater seasonal variations in use ${ }^{17}$. In a previous seasonality study, antibiotics

218 with higher rates of use showed stronger correlations between seasonal use and resistance ${ }^{14}$.

219 In addition, use of macrolides and penicillins have been shown to be more strongly correlated

220 with resistance than less frequently prescribed antibiotics ${ }^{9}$.

222 Second, the observed winter peaks in resistance may be explained by increased sampling of

223 demographics and types of infections with higher overall rates of resistance, rather than

224 selection by antibiotic use. Rates of resistance have been shown to vary by age, sex, and site of

225 infection ${ }^{30-32}$; and, the incidence of infections from each of these groups can also vary by

226 season $^{26,33,34}$. As such, an increased incidence of infections from groups with higher rates of

227 resistance could in turn lead to a winter spike in resistance, irrespective of patterns of use.

228

229 There were several limitations to this study. First, while antibiotic use is one important driver of

230 resistance, we cannot rule out other seasonal effects that could also contribute to seasonal

231 variations in resistance, such as a sampling bias for demographics or infection types with higher

232 levels of resistance during certain seasons. Second, although our study analyzed data from a

233 single city, there is still some disparity between the populations represented in the antibiotic use

234 and resistance datasets. We compared outpatient antibiotic use data from $97 \%$ of Boston, MA

235 residents under age 65 to antibiotic resistance data from both inpatients and outpatients at two

236 major Boston-area hospitals, with patient populations that skew towards older ages. Previous

237 studies have shown that community antibiotic use has strong impact on resistance in both the

238 hospital and community settings ${ }^{35,36}$. However, other aspects of the patient population in the

239 resistance dataset, such as their age distribution, may not be representative of the overall 
medRxiv preprint doi: https://doi.org/10.1101/2020.12.21.20248670; this version posted December 22, 2020. The copyright holder for this preprint (which was not certified by peer review) is the author/funder, who has granted medRxiv a license to display the preprint in perpetuity.

It is made available under a CC-BY-NC-ND 4.0 International license .

240 population in the use dataset, potentially limiting our conclusions. Finally, due to data limitations,

241 the antibiotic use and resistance datasets for each species and antibiotic often spanned

242 overlapping but different year ranges. Therefore, we aggregated monthly use and resistance

243 data across years to perform our correlation analyses, assuming that seasonal patterns of use

244 and resistance were stable across the years included in our study.

246 In conclusion, we found evidence of a seasonal relationship between antibiotic use and

247 resistance, which varied widely across antibiotic classes but was largely consistent across the

248 three bacterial species, S. aureus, E. coli, and K. pneumoniae. While antibiotic use showed

249 varied seasonal patterns across classes, resistance to all antibiotics peaked in the winter to

250 spring, resulting in large variations in the correlation between cognate pairs. This indicates that

251 the simplest model of antibiotic use independently selecting for resistance to the same antibiotic

252 is inadequate and underscores the need to identify additional factors that shape the use-

253 resistance relationship across diverse species and antibiotics. In addition, these findings may

254 contribute to guiding future stewardship efforts by identifying antibiotic targets, such as

255 penicillins and macrolides, that may have the broadest effect in reducing overall resistance.

257 Materials and Methods

258 Antibiotic use data. Outpatient antibiotic use data was obtained from the Massachusetts All

259 Payer Claims Database ${ }^{37}$, which covers $>94 \%$ of outpatient prescriptions claims for

260 Massachusetts residents under the age of $65^{38}$. Rates of use for each antibiotic class were

261 measured as the number of antibiotic claims per 1000 people for each month from January

2622011 to May 2015. This data was subset to include only individuals residing in 'Boston City'

263 census tracks, as defined by the US Census Bureau ${ }^{39}$, to capture the antibiotic use patterns in

264 the communities served by the hospitals in our resistance dataset. We aggregated use data by

265 antibiotic class according to the WHO ATC index ${ }^{40}$ for 5 antibiotic classes, which together make 
medRxiv preprint doi: https://doi.org/10.1101/2020.12.21.20248670; this version posted December 22, 2020. The copyright holder for this preprint (which was not certified by peer review) is the author/funder, who has granted medRxiv a license to display the preprint in perpetuity.

It is made available under a CC-BY-NC-ND 4.0 International license .

266

267

268

269

270

271

272

273

274

275

276

277

278

279

280

281

282

283

284

285

286

287

288

289

290

up 74\% of the total outpatient antibiotic claims in Boston: penicillins (ATC code, J01C), macrolides (ATC code, J01F), quinolones (ATC code, J01M), tetracyclines (ATC code, J01A), and nitrofurans (ATC code, JO1XE). The distribution of use of individual antibiotics within each class is shown in Table S1.

Antibiotic resistance data. Clinical microbiology data was obtained for $S$. aureus, E. coli, and K. pneumoniae isolates collected at two tertiary care hospitals in Boston, MA: Brigham and Women's Hospital (BWH) and Massachusetts General Hospital (MGH), from 2007-2019 and 2007-2016, respectively. Included in this analysis were all non-surveillance isolates from inpatients and outpatients of all demographics, collected from the 5 most common body sites across the 3 species: blood, skin and soft tissue, abscess/fluid, respiratory tract, and urinary tract. The distribution of isolates by hospital, patient demographic group, and body site is shown in Table S2. Isolates of the same species that were collected from the same patient within 2 weeks were assumed to represent a single infection and thus treated as a single isolate. Our final dataset comprised 47,219 S. aureus, 131,856 E. coli, and 27,245 K. pneumoniae isolates.

Antibiotic susceptibility testing was performed on each isolate either by automated broth microdilution (Vitek 2, Biomerieux, Marcy l'Etoile, France) or by E-test. Resulting minimum inhibitory concentration (MIC) values were $\log _{2}$-transformed. Due to variations in hospital testing guidelines across the years, we excluded tests on isolates that did not report an MIC value, either because a different test method was used (e.g. disk diameter) or due to missing data. We then excluded years/months from our analysis for each species-antibiotic combination in each hospital where MIC values were reported for less than $80 \%$ of isolates or only a subset of isolate types (e.g., only testing nitrofurantoin resistance in urinary tract isolates). Table S3 lists date ranges for each species-antibiotic combination included in our analysis. For each species, 
medRxiv preprint doi: https://doi.org/10.1101/2020.12.21.20248670; this version posted December 22, 2020. The copyright holder for this preprint (which was not certified by peer review) is the author/funder, who has granted medRxiv a license to display the preprint in perpetuity.

It is made available under a CC-BY-NC-ND 4.0 International license .

291 we analyzed MIC data for individual antibiotics that are in each of the 5 corresponding antibiotic

292 use classes, as listed in Table S3.

293

294 Statistical methods. We quantified the extent of seasonality in antibiotic use and resistance by

295 fitting the use and MIC data to a pair of mathematical models, based on a previously described

296 method $^{16}$. Both models consist of a sinusoidal component to describe seasonal deviations from

297 average year-round use and MICs and a linear component to adjust for secular trends in use

298 and resistance across years. To describe the seasonality of use, monthly claims data for each

299 antibiotic class were fit to

$$
a_{i} \sim A_{u s e} \cos \left[\omega\left(t_{i}-P_{u s e}\right)\right]+B_{y(i)} t_{i}+C_{y(i)}
$$

300

301

303

304

305

306 307 intercept terms.

308

309

310

311

312

313

where $a_{i}$ is the reported claims $/ 1000$ people during month $t_{i}, A_{u s e}$ is the amplitude of use seasonality, $\omega$ is the frequency of seasonality where $\omega=\frac{2 \pi}{\text { period }}, P_{u s e}$ is the phase of use seasonality, and $B_{y(i)}$ and $C_{y(i)}$ are the within-year slope and intercept terms. To describe the seasonality of resistance, MICs for each isolate were fit to

$$
y_{i} \sim A_{M I C} \cos \left[\omega\left(t_{i}-P_{M I C}\right)\right]+B_{h(i)} t_{i}+C_{h(i)}
$$

where $y_{i}$ is the $\log _{2}$-transformed MIC and $t_{i}$ is the month of collection of the $i^{\text {th }}$ isolate, $A_{M I C}$ is the amplitude of resistance seasonality, $\omega$ is the frequency of seasonality where $\omega=\frac{2 \pi}{\text { period }}, P_{M I C}$ is the phase of resistance seasonality, and $B_{h(i)}$ and $C_{h(i)}$ are the within hospital/year slope and

The amplitude, phase, slope, and intercept terms in both models were estimated by non-linear regression, using the $n / s$ function in $\mathrm{R}$ (version 3.6.2). We examined periods of both 12 and 6 months to account for annual or biannual cycles in use and resistance. To determine whether to use a 12- or 6-month period for each species-antibiotic combination, we performed model comparisons using the Akaike information criterion (AIC) and used the period that resulted in 
medRxiv preprint doi: https://doi.org/10.1101/2020.12.21.20248670; this version posted December 22, 2020. The copyright holder for this preprint (which was not certified by peer review) is the author/funder, who has granted medRxiv a license to display the preprint in perpetuity.

It is made available under a CC-BY-NC-ND 4.0 International license .

314 the lower AIC (Tables S4 \& S5). We determined that there was seasonality in use or resistance

315 if the $95 \%$ confidence interval of the amplitude did not include 0 . We accounted for multiple

316 comparisons by applying the Benjamini-Hochberg correction with a $5 \%$ false discovery rate to

317 the p-values of the amplitude estimates.

Next, we quantified the association between the observed seasonal patterns of use and resistance using Spearman's rank correlations. To eliminate the impact of annual trends, we calculated correlations between the average monthly seasonal deviates in use and resistance, rather than the raw use and MIC data. We define a 'seasonal deviate' as the deviation in use (in claims per 1000 people) or resistance (in doubling dilutions) at a given time of year from the year-round average, which we estimated by the linear component of the models described above. Seasonal deviates in use for each year and month were calculated as

$$
a_{i}^{\prime}=a_{i}-\widehat{B_{y(l)}} t_{i}-\widehat{C_{y(l)}}
$$

where $a_{i}^{\prime}$ is the seasonal deviate in use of the reported claims/1000 people during month $t_{i}, a_{i}$ is

327 the reported claims/1000 people during month $t_{i}$, and $\widehat{B_{y(l)}}$ and $\widehat{C_{y(l)}}$ are the within-year slope

328 and intercept terms estimated from the model fit (Eqn. 1) for the corresponding year. Similarly, seasonal deviates in resistance for each isolate were calculated as

$$
y_{i}^{\prime}=y_{i}-\widehat{B_{h(l)}} t_{i}-\widehat{C_{h(l)}}
$$

330 where $y_{i}^{\prime}$ is the seasonal deviate of the $\log _{2}$-transformed MIC of the $i^{\text {th }}$ isolate, $y_{i}$ is the $\log _{2^{-}}$

331 transformed MIC of the $i^{t h}$ isolate, $t_{i}$ is the month of collection of the $i^{t h}$ isolate, and $\widehat{B_{h(l)}}$ and

$332 \widehat{C_{h(l)}}$ are the hospital/year slope and intercept estimated from the model fit (Eqn. 2) for the 333 hospital and year that the $i^{\text {th }}$ isolate was collected in.

335 Since we observed some seasonal patterns of resistance that better aligned with use of noncognate antibiotic classes, we calculated use-resistance correlations between each pairwise 
medRxiv preprint doi: https://doi.org/10.1101/2020.12.21.20248670; this version posted December 22, 2020. The copyright holder for this preprint (which was not certified by peer review) is the author/funder, who has granted medRxiv a license to display the preprint in perpetuity.

It is made available under a CC-BY-NC-ND 4.0 International license .

337 combination of target antibiotics and use classes. We only included use-resistance pairs in this

338 analysis for which both use and resistance met our criterion for seasonality.

339

340 All analyses were performed in $\mathrm{R}$ version $3 \cdot 6.2^{41}$. Code is available at:

341 https://github.com/gradlab/use-resistance-seasonality

342

\section{Acknowledgements}

344 The authors thank R. Monina Klevens for assistance in acquiring the antibiotic prescribing data

345 and Enterprise Research Infrastructure \& Services at Partners HealthCare for their

346 computational resources and support. This work was supported by funds from the HSPH Dean's

347 Award (to Y.H.G.) and Wellcome Trust (to Y.H.G.). D.S.S. is supported by the National Institutes

348 of Health training grant (T32Al132120).

350 Competing interests

351 Y. H. G. and M. L. have received grant support from Pfizer. The other authors declare no

352 competing interests. 
medRxiv preprint doi: https://doi.org/10.1101/2020.12.21.20248670; this version posted December 22, 2020. The copyright holder for this preprint (which was not certified by peer review) is the author/funder, who has granted medRxiv a license to display the preprint in perpetuity.

It is made available under a CC-BY-NC-ND 4.0 International license .

\section{References}

354 1. U.S. Centers for Disease Control and Prevention. Antibiotic resistance threats in the

355 United States, 2019. https://www.cdc.gov/drugresistance/pdf/threats-report/2019-ar-

356 threats-report-508.pdf. Published 2019. Accessed September 18, 2020.

357 2. Jit M, Ng DHL, Luangasanatip N, et al. Quantifying the economic cost of antibiotic resistance and the impact of related interventions: Rapid methodological review, conceptual framework and recommendations for future studies. BMC Med. 2020;18(1):38. doi:10.1186/s12916-020-1507-2

361

362

363

364

365

366

367

3. Tedijanto C, Olesen SW, Grad YH, Lipsitch M. Estimating the proportion of bystander selection for antibiotic resistance among potentially pathogenic bacterial flora. Proc Natl Acad Sci U S A. 2018;115(51):E11988-E11995. doi:10.1073/pnas.1810840115

4. Goossens H, Ferech M, Vander Stichele R, Elseviers M. Outpatient antibiotic use in Europe and association with resistance: a cross-national database study. Lancet. 2005. doi:10.1016/S0140-6736(05)17907-0

5. García-Rey C, Aguilar L, Baquero F, Casal J, Dal-Ré R. Importance of local variations in antibiotic consumption and geographical differences of erythromycin and penicillin resistance in Streptococcus pneumoniae. J Clin Microbiol. 2002;40(1):159-164. doi:10.1128/JCM.40.1.159-164.2002

6. Bronzwaer SLAM, Cars O, Buchholz U, et al. The relationship between antimicrobial use and antimicrobial resistance in Europe. Emerg Infect Dis. 2002;8(3):278-282. doi:10.3201/eid0803.010192

7. Van De Sande-Bruinsma N, Grundmann H, Verloo D, et al. Antimicrobial drug use and resistance in Europe. Emerg Infect Dis. 2008;14(11):1722-1730. doi:10.3201/eid1411.070467

8. Hicks LA, Chien Y-W, Taylor TH, Haber M, Klugman KP. Outpatient Antibiotic Prescribing and Nonsusceptible Streptococcus pneumoniae in the United States, 1996-2003. Clin 
medRxiv preprint doi: https://doi.org/10.1101/2020.12.21.20248670; this version posted December 22, 2020. The copyright holder for this preprint (which was not certified by peer review) is the author/funder, who has granted medRxiv a license to display the preprint in perpetuity.

It is made available under a CC-BY-NC-ND 4.0 International license .

Infect Dis. 2011;53(7):631-639. doi:10.1093/cid/cir443

9. Olesen SW, Barnett ML, Macfadden DR, et al. The distribution of antibiotic use and its association with antibiotic resistance. Elife. 2018;7. doi:10.7554/eLife.39435

10. Bell BG, Schellevis F, Stobberingh E, Goossens H, Pringle M. A systematic review and meta-analysis of the effects of antibiotic consumption on antibiotic resistance. BMC Infect Dis. 2014;14(1):13. doi:10.1186/1471-2334-14-13

11. Olesen SW, Grad YH. Deciphering the Impact of Bystander Selection for Antibiotic Resistance in Neisseria gonorrhoeae. J Infect Dis. 2020;221(7):1035. doi:10.1093/infdis/jiz156

12. Olesen SW, Lipsitch M, Grad YH. The role of "spillover" in antibiotic resistance. bioRxiv. June 2019:536714. doi:10.1101/536714

13. Dagan R, Barkai G, Givon-Lavi N, et al. Seasonality of Antibiotic-Resistant Streptococcus pneumoniae That Causes Acute Otitis Media: A Clue for an Antibiotic-Restriction Policy? J Infect Dis. 2008;197(8):1094-1102. doi:10.1086/528995

14. Sun L, Klein EY, Laxminarayan R. Seasonality and Temporal Correlation between Community Antibiotic Use and Resistance in the United States. Clin Infect Dis. 2012;55(5):687-694. doi:10.1093/cid/cis509

15. Ramsey EG, Royer J, Bookstaver PB, et al. Seasonal variation in antimicrobial resistance rates of community-acquired Escherichia coli bloodstream isolates. Int $J$ Antimicrob Agents. 2019;54(1):1-7. doi:10.1016/J.IJANTIMICAG.2019.03.010

16. Olesen SW, Torrone EA, Papp JR, Kirkcaldy RD, Lipsitch M, Grad YH. Azithromycin Susceptibility Among Neisseria gonorrhoeae Isolates and Seasonal Macrolide Use. J Infect Dis. 2019;219(4):619-623. doi:10.1093/infdis/jiy551

17. Suda KJ, Hicks LA, Roberts RM, Hunkler RJ, Taylor TH. Trends and seasonal variation in outpatient antibiotic prescription rates in the united states, 2006 to 2010 . Antimicrob Agents Chemother. 2014;58(5):2763-2766. doi:10.1128/AAC.02239-13 
medRxiv preprint doi: https://doi.org/10.1101/2020.12.21.20248670; this version posted December 22, 2020. The copyright holder for this preprint (which was not certified by peer review) is the author/funder, who has granted medRxiv a license to display the preprint in perpetuity.

It is made available under a CC-BY-NC-ND 4.0 International license .

405

406

407

408

409

410

411

412

413

414

415

416

417

418

419

420

421

422

423

424

425

426

427

428

429

430

18. Kluytmans J, Van Belkum A, Verbrugh H. Nasal carriage of Staphylococcus aureus: Epidemiology, underlying mechanisms, and associated risks. Clin Microbiol Rev. 1997;10(3):505-520. doi:10.1128/cmr.10.3.505-520.1997

19. Huttenhower C, Gevers D, Knight R, et al. Structure, function and diversity of the healthy human microbiome. Nature. 2012;486(7402):207-214. doi:10.1038/nature11234

20. Berchick ER, Barnett JC, Upton RD. Health Insurance Coverage in the United States: 2018 Current Population Reports.; 2019.

21. Blanquart F, Lehtinen S, Fraser C. An evolutionary model to predict the frequency of antibiotic resistance under seasonal antibiotic use, and an application to Streptococcus pneumoniae. 2017. doi:10.1098/rspb.2017.0679

22. Guay DR. An update on the role of nitrofurans in the management of urinary tract infections. Drugs. 2001;61(3):353-364. doi:10.2165/00003495-200161030-00004

23. Stamm WE, McKevitt M, Roberts PL, White NJ. Natural History of Recurrent Urinary Tract Infections in Women. Rev Infect Dis. 1991;13(1):77-84. doi:10.1093/CLINIDS/13.1.77

24. Anderson JE. Seasonality of symptomatic bacterial urinary infections in women. $J$ Epidemiol Community Health. 1983;37:286-290.

25. Czaja CA, Scholes D, Hooton TM, Stamm WE. Population-Based Epidemiologic Analysis of Acute Pyelonephritis. Clin Infect Dis. 2007;45(3):273-280. doi:10.1086/519268

26. Rosello A, Pouwels KB, Domenech De Cellès M, et al. Seasonality of urinary tract infections in the United Kingdom in different age groups: Longitudinal analysis of The Health Improvement Network (THIN). Epidemiol Infect. 2018;146(1):37-45. doi:10.1017/S095026881700259X

27. Hooper DC. Clinical applications of quinolones. Biochim Biophys Acta - Gene Struct Expr. 1998;1400(1-3):45-61. doi:10.1016/S0167-4781(98)00127-4

28. Kanjilal S, Abdul Sater MR, Thayer M, et al. Trends in antibiotic susceptibility in 
medRxiv preprint doi: https://doi.org/10.1101/2020.12.21.20248670; this version posted December 22, 2020. The copyright holder for this preprint (which was not certified by peer review) is the author/funder, who has granted medRxiv a license to display the preprint in perpetuity.

It is made available under a CC-BY-NC-ND 4.0 International license .

431

432

433

434

435

436

437

438

439

440

441

442

443

444

445

446

447

448

449

450

451

452

453

454

455

456

staphylococcus aureus in Boston, Massachusetts, from 2000 to 2014. Ledeboer NA, ed. J Clin Microbiol. 2018;56(1). doi:10.1128/JCM.01160-17

29. Chang H-H, Cohen T, Grad YH, Hanage WP, O’Brien TF, Lipsitch M. Origin and Proliferation of Multiple-Drug Resistance in Bacterial Pathogens. Microbiol Mol Biol Rev. 2015;79(1):101-116. doi:10.1128/mmbr.00039-14

30. Mcgregor JC, Elman MR, Bearden DT, Smith DH. Sex- and age-specific trends in antibiotic resistance patterns of Escherichia coli urinary isolates from outpatients. BMC Fam Pract. 2013;14:25. doi:10.1186/1471-2296-14-25

31. Garcia A, Delorme T, Nasr P. Patient age as a factor of antibiotic resistance in methicillinresistant staphylococcus aureus. J Med Microbiol. 2017;66(12):1782-1789. doi:10.1099/jmm.0.000635

32. Lagacé-Wiens PRS, DeCorby MR, Baudry PJ, Hoban DJ, Karlowsky JA, Zhanel GG. Differences in antimicrobial susceptibility in Escherichia coli from Canadian intensive care units based on regional and demographic variables. Can J Infect Dis Med Microbiol. 2008;19(4):282-286. doi:10.1155/2008/568458

33. Simmering J, Tang F, Cavanaugh J, Polgreen L, Polgreen PM. Trends and Seasonal Effects in Hospitalizations for Urinary Tract Infection Differ by Age and Sex. Open Forum Infect Dis. 2015;2(suppl_1). doi:10.1093/ofid/ofv133.1128

34. Leekha S, Diekema DJ, Perencevich EN. Seasonality of staphylococcal infections. Clin Microbiol Infect. 2012;18(10):927-933. doi:10.1111/j.1469-0691.2012.03955.x

35. Knight GM, Costelloe C, Deeny SR, et al. Quantifying where human acquisition of antibiotic resistance occurs: A mathematical modelling study. BMC Med. 2018;16(1):137. doi:10.1186/s12916-018-1121-8

36. Macfadden DR, Fisman DN, Hanage WP, Lipsitch M. The Relative Impact of Community and Hospital Antibiotic Use on the Selection of Extended-spectrum Beta-lactamaseproducing Escherichia coli. Clin Infect Dis. 2019;69(1):182-188. doi:10.1093/cid/ciy978 
medRxiv preprint doi: https://doi.org/10.1101/2020.12.21.20248670; this version posted December 22, 2020. The copyright holder for this preprint (which was not certified by peer review) is the author/funder, who has granted medRxiv a license to display the preprint in perpetuity. It is made available under a CC-BY-NC-ND 4.0 International license .

457 37. Massachusetts All Payer Claims Database. https://www.chiamass.gov/ma-apcd/.

$458 \quad$ Accessed September 16, 2020.

459 38. Klevens RM, Caten E, Olesen SW, DeMaria A, Troppy S, Grad YH. Outpatient Antibiotic

$460 \quad$ Prescribing in Massachusetts, 2011-2015. Open Forum Infect Dis. 2019;6(5).

461 doi:10.1093/ofid/ofz169

462 39. US Census Bureau. https://data.census.gov/cedsci/. Published 2020. Accessed

$463 \quad$ September 16, 2020.

464 40. WHOCC - ATC/DDD Index. https://www.whocc.no/atc_ddd_index/. Accessed June 13, 4652020.

466 41. R Core Team (2019). R: A language and environment for statistical computing. R 467 Foundation for Statistical Computing, Vienna, Austria. URL https://www.R-project.org/. 


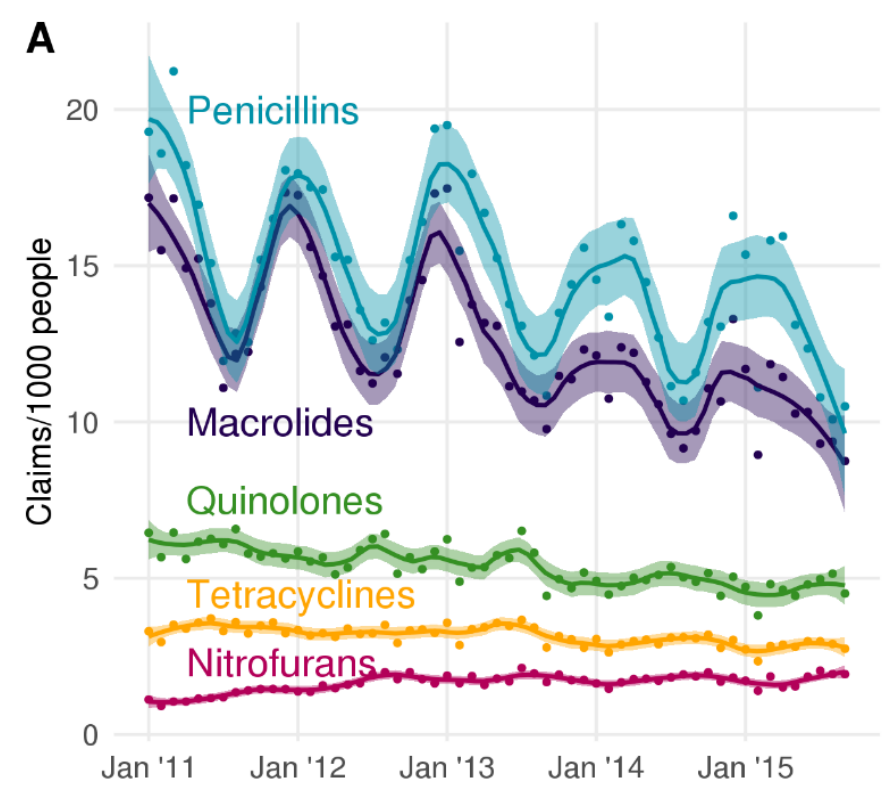

469

470

471

472

473 Points indicate monthly mean seasonal deviates in antibiotic claims per 1000 people and error

474

475

476
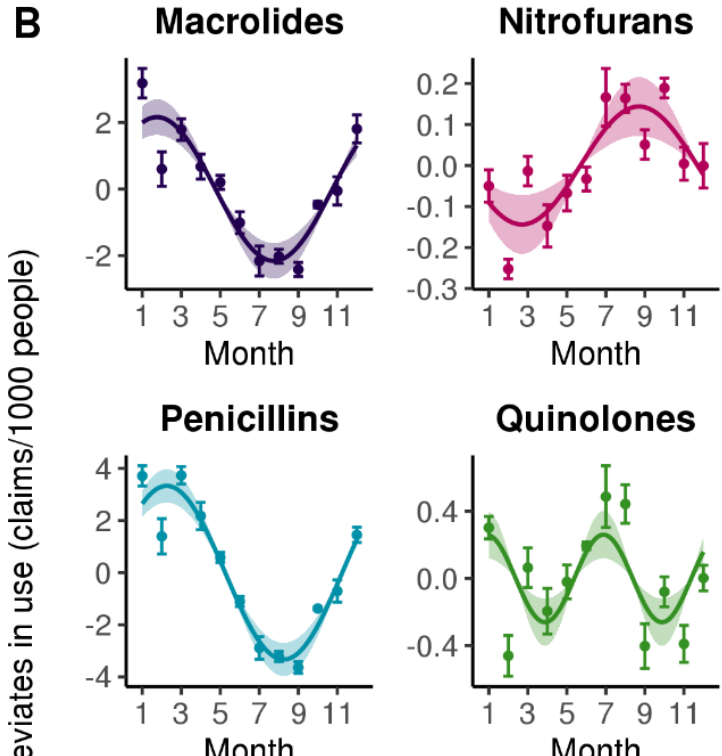

Quinolones

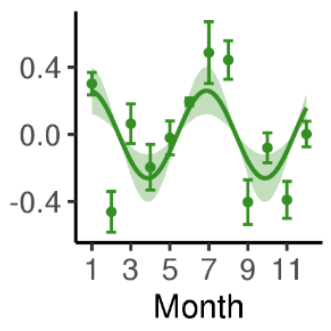

Tetracyclines

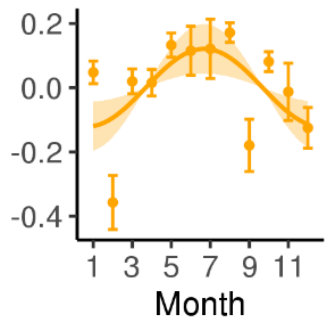

Figure 1. Seasonal patterns of antibiotic use by class. (A) Monthly antibiotic claims per 1000 people in Boston, MA from 2011 to $2015^{37}$. Lines indicate LOESS smoothing curves and shaded regions indicate $95 \%$ confidence intervals. (B) Sinusoidal model fits for monthly prescribing rate. bars indicate the standard error of the mean. Lines indicate the point estimate for the amplitude and phase of the sinusoidal model. Shaded regions indicate the $95 \%$ confidence intervals for the amplitude. 


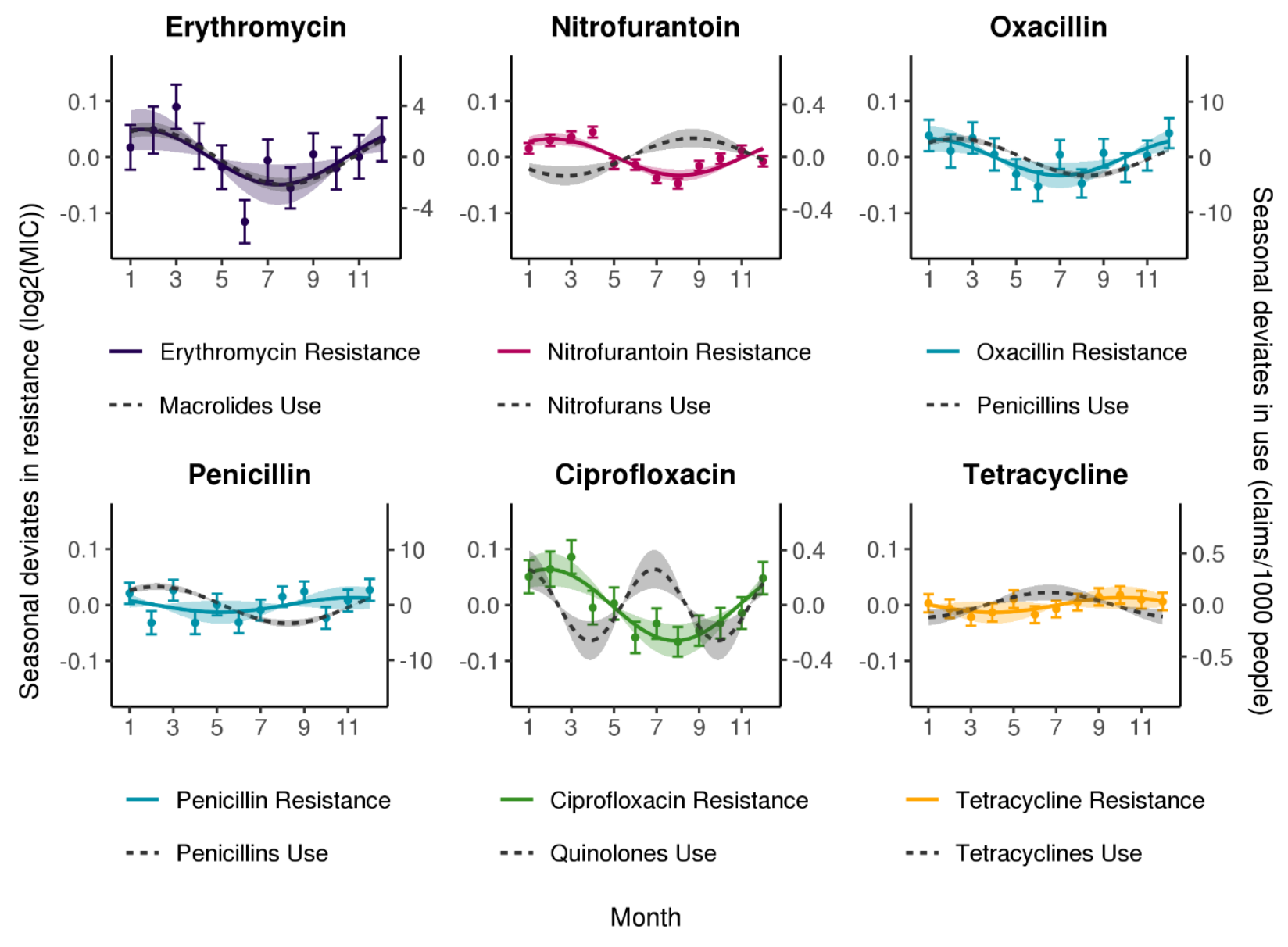

478 Figure 2. Seasonality of antibiotic use and resistance by class in Staphylococcus aureus.

479 Solid lines indicate point estimates of the amplitude and phase from the best-fitting sinusoidal

480 models of resistance to each antibiotic, colored by class. Dashed grey lines indicate point

481 estimates of the amplitude and phase of sinusoidal models for use of the corresponding

482 antibiotic class. Points indicate the monthly mean seasonal deviates in doubling dilutions and

483 error bars indicate the standard error of the mean. Shaded regions indicate the $95 \%$ confidence

484 intervals for the amplitude. 
S. aureus

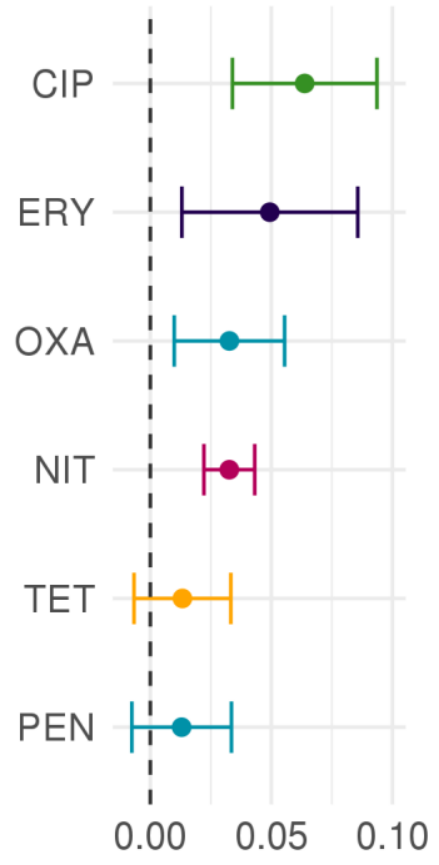

E. coli

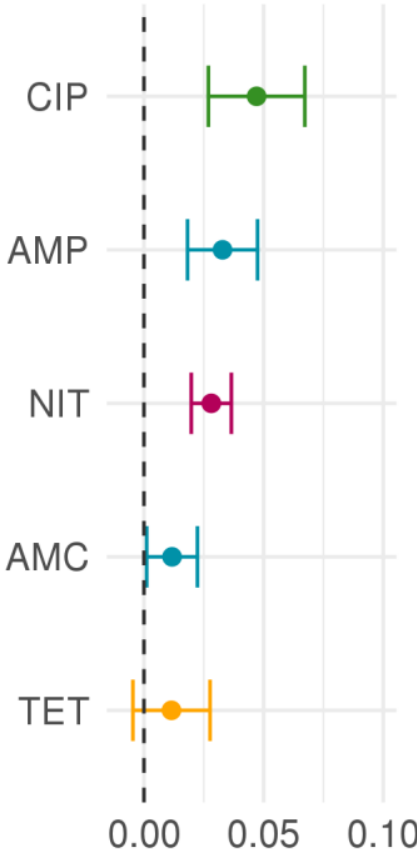

K. pneumoniae

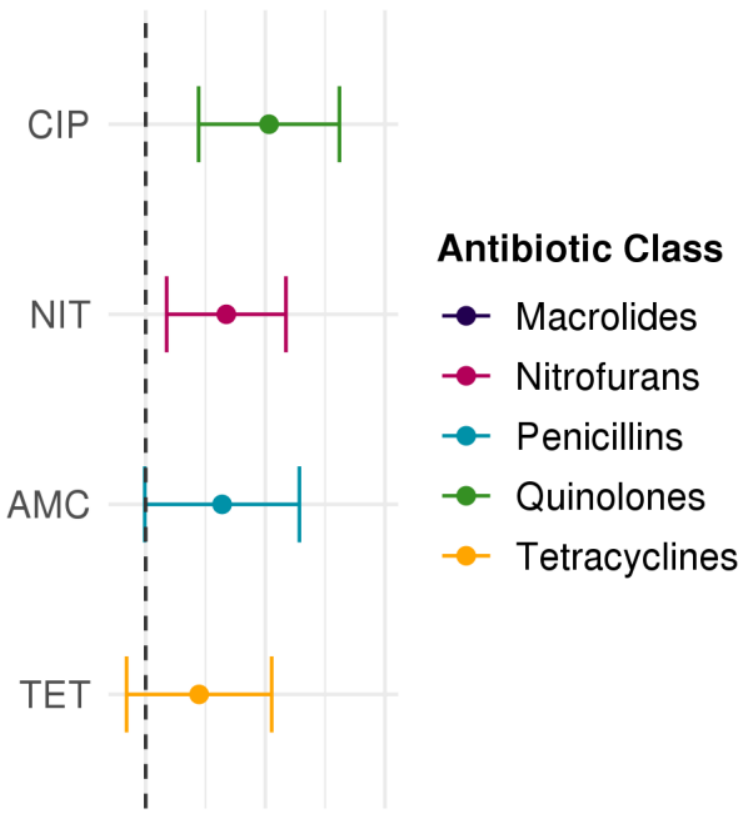

Amplitude of seasonality (log2(MIC) deviates)

487 Figure 3. Amplitudes of seasonality of resistance by species and antibiotic class.

488 Comparison of amplitudes estimated from best-fitting sinusoidal models of resistance across

489 antibiotics in Staphylococcus aureus, Escherichia coli, and Klebsiella pneumoniae. Error bars

490 indicate $95 \%$ confidence intervals of the amplitude. Point color indicates the antibiotic class.

491 AMC, Amoxicillin-Clavulanate; AMP, Ampicillin; CIP, Ciprofloxacin; ERY, Erythromycin; NIT,

492 Nitrofurantoin; OXA, Oxacillin; PEN, Penicillin; TET, Tetracycline. 
S. aureus / ERY

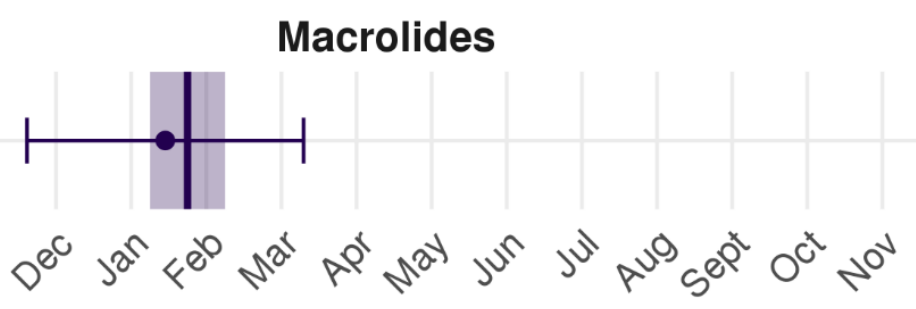

Nitrofurans

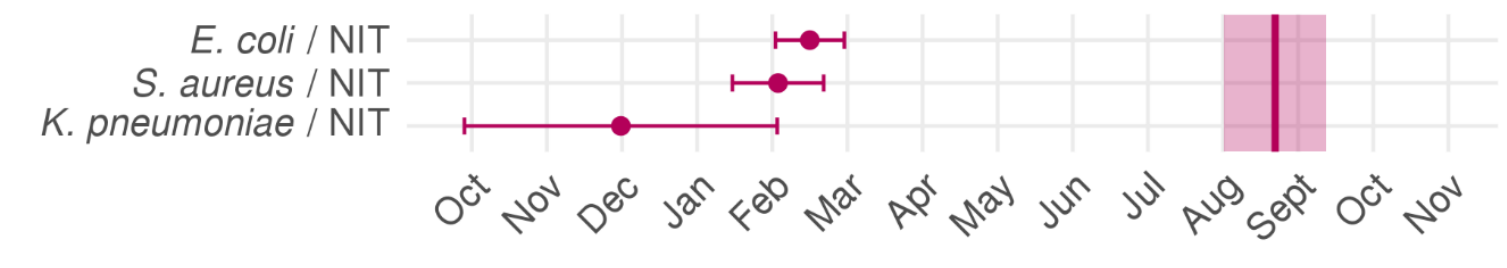

Penicillins

E. coli / AMP

E. coli / AMC

S. aureus / OXA
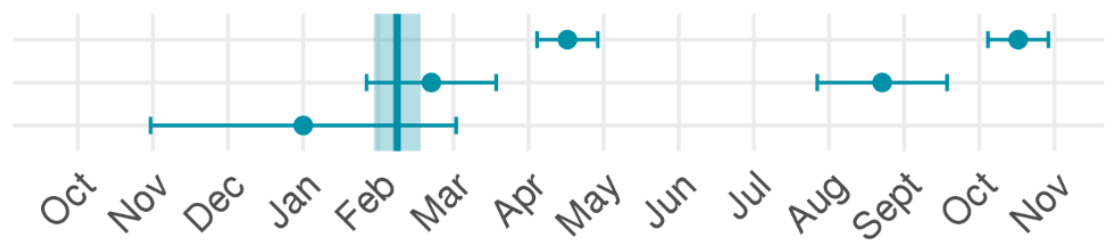

\section{Quinolones}

K. pneumoniae / CIP

S. aureus / CIP
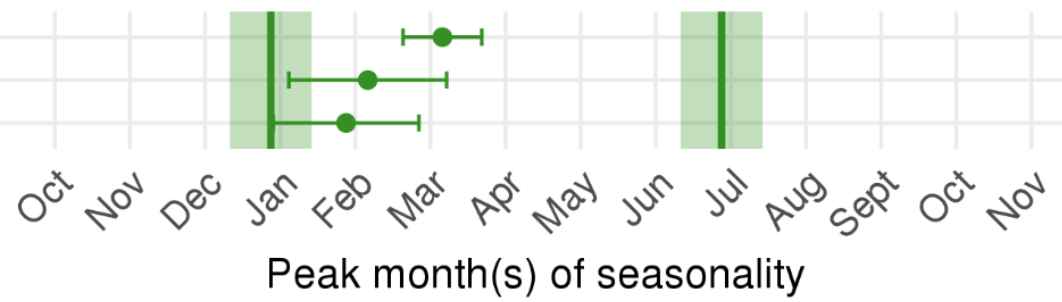

Figure 4. Phases of seasonality of use and resistance by species and antibiotic class.

Points indicate peak month(s) of seasonal resistance estimated by the best-fitting sinusoidal

model for each species-antibiotic combination, and error bars indicate the $95 \%$ confidence

intervals. Vertical lines indicate the peak month(s) of seasonal use estimated by the best-fitting sinusoidal model for each antibiotic class, and the shaded regions indicate the $95 \%$ confidence intervals. Included are species-antibiotic combinations for which the amplitude met our criteria for seasonality (95\% confidence intervals did not cross 0). AMC, Amoxicillin-Clavulanate; AMP,

501 Ampicillin; CIP, Ciprofloxacin; ERY, Erythromycin; NIT, Nitrofurantoin; OXA, Oxacillin. 
medRxiv preprint doi: https://doi.org/10.1101/2020.12.21.20248670; this version posted December 22, 2020. The copyright holder for this preprint (which was not certified by peer review) is the author/funder, who has granted medRxiv a license to display the preprint in perpetuity.

It is made available under a CC-BY-NC-ND 4.0 International license.

\section{S. aureus}

Resistance / Use

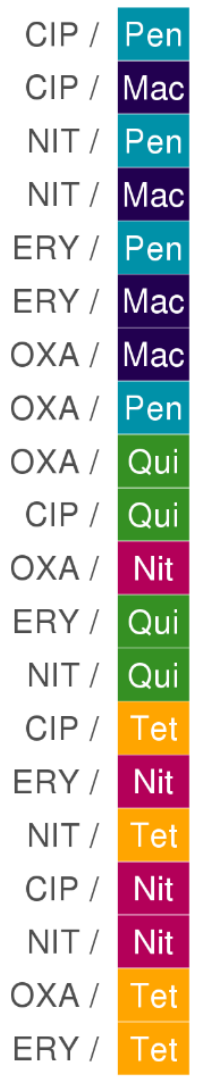

502
E. coli

Resistance / Use

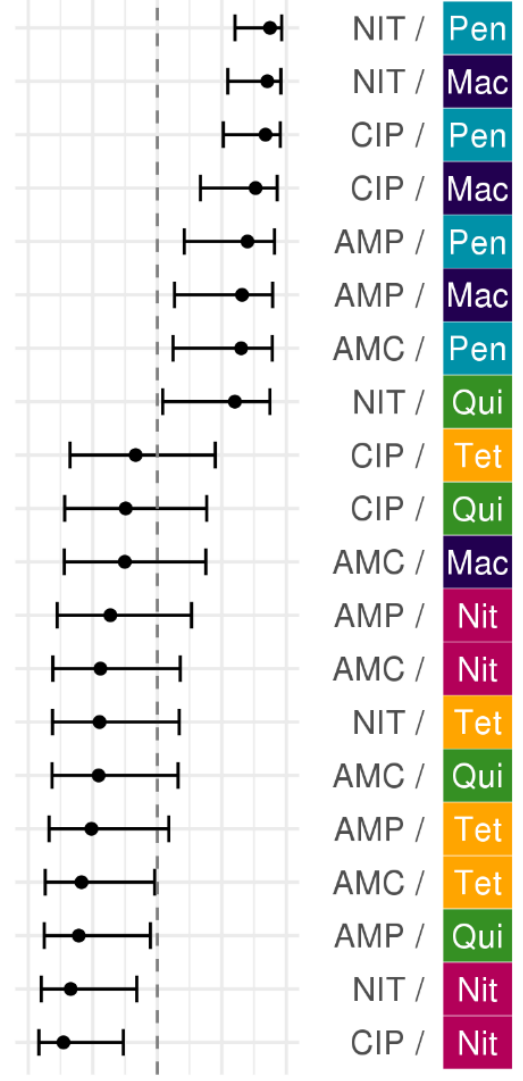

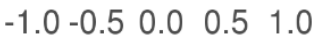

Spearman's $\rho$

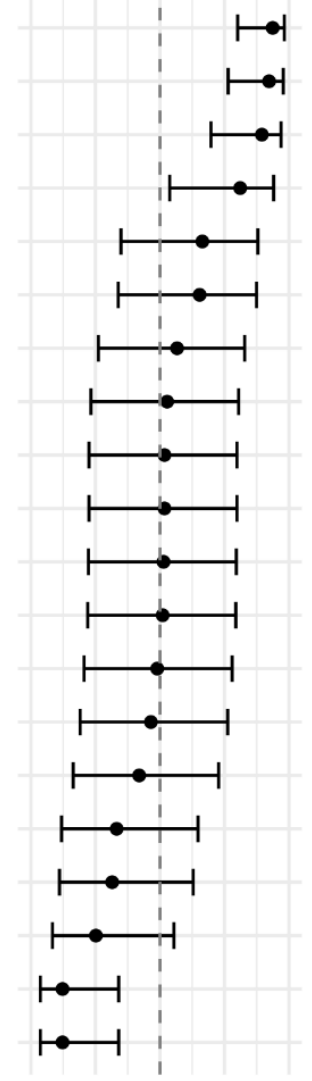

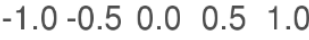

Spearman's $\rho$
K. pneumoniae

Resistance / Use

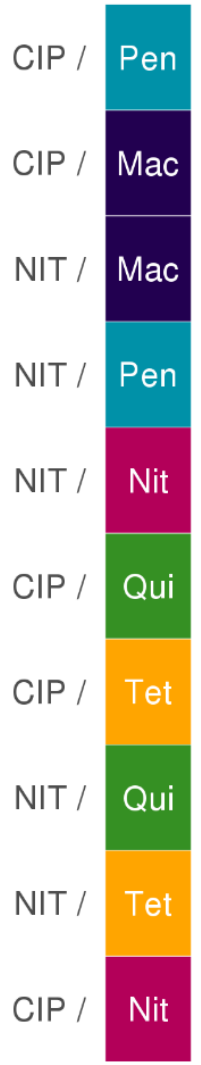

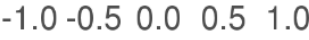

Spearman's $\rho$

Figure 5. Seasonal resistance to multiple antibiotics is positively correlated with seasonal use of penicillins and macrolides. Spearman's rank correlation coefficients were calculated between the mean seasonal deviate in resistance (in doubling dilutions) and the mean seasonal deviate in use (in claims/1000 people) in each month for every pairwise combination of antibiotics and classes. Error bars indicate the $95 \%$ confidence intervals. Colors indicate the use antibiotic class. Mac, Macrolides; Nit, Nitrofurantoin; Pen, Penicillins; Qui, Quinolones; Tet, Tetracyclines. AMC, Amoxicillin-Clavulanate; AMP, Ampicillin; CIP, Ciprofloxacin; ERY, Erythromycin; NIT, Nitrofurantoin; OXA, Oxacillin. 


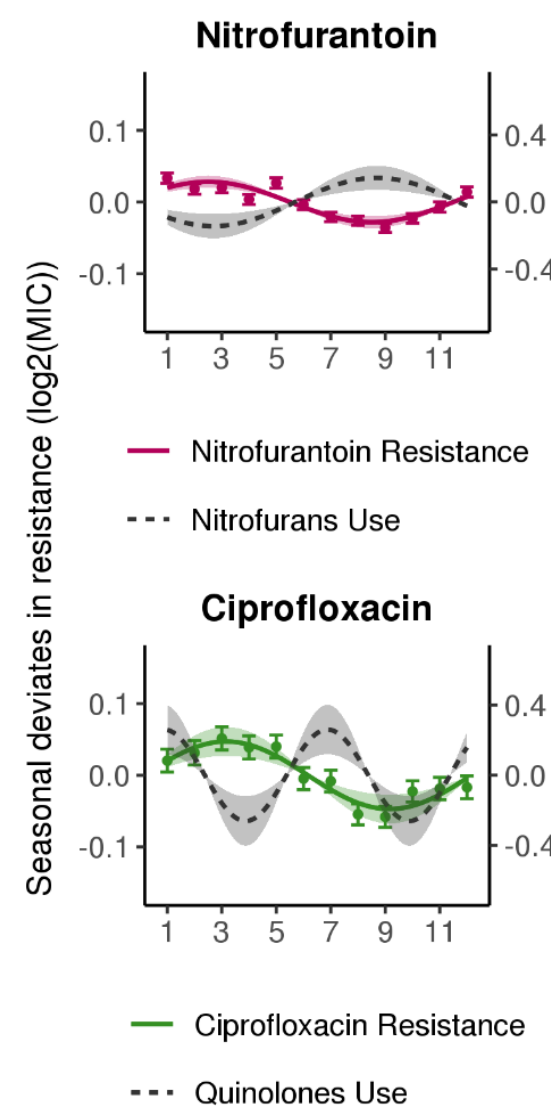

511

\section{Supplemental Figure 1. Seasonality of antibiotic use and resistance by class in}

513 Escherichia coli. Solid lines indicate point estimates of the amplitude and phase from the best-

514 fitting sinusoidal models of resistance to each antibiotic, colored by class. Dashed grey lines

515 indicate point estimates of the amplitude and phase from sinusoidal models of use of the

516 corresponding antibiotic class. Points indicate the monthly mean seasonal deviates in doubling

517 dilutions and error bars indicate the standard error of the mean. Shaded regions indicate the
Amox/Clav

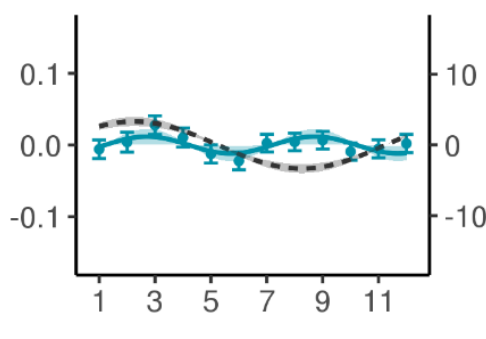

- Amox/Clav Resistance

-.. Penicillins Use

Tetracycline

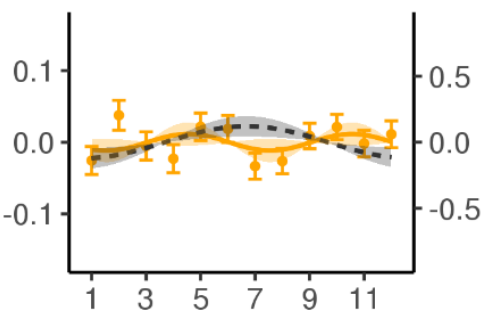

- Tetracycline Resistance

-.. Tetracyclines Use

Month

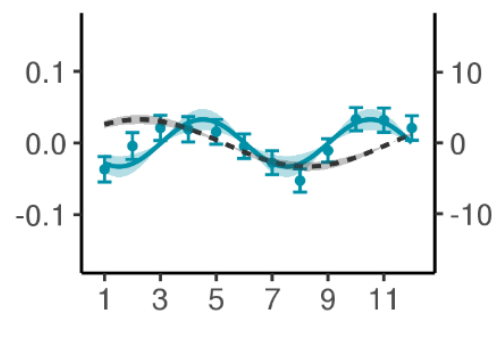

- Ampicillin Resistance

-.. Penicillins Use 


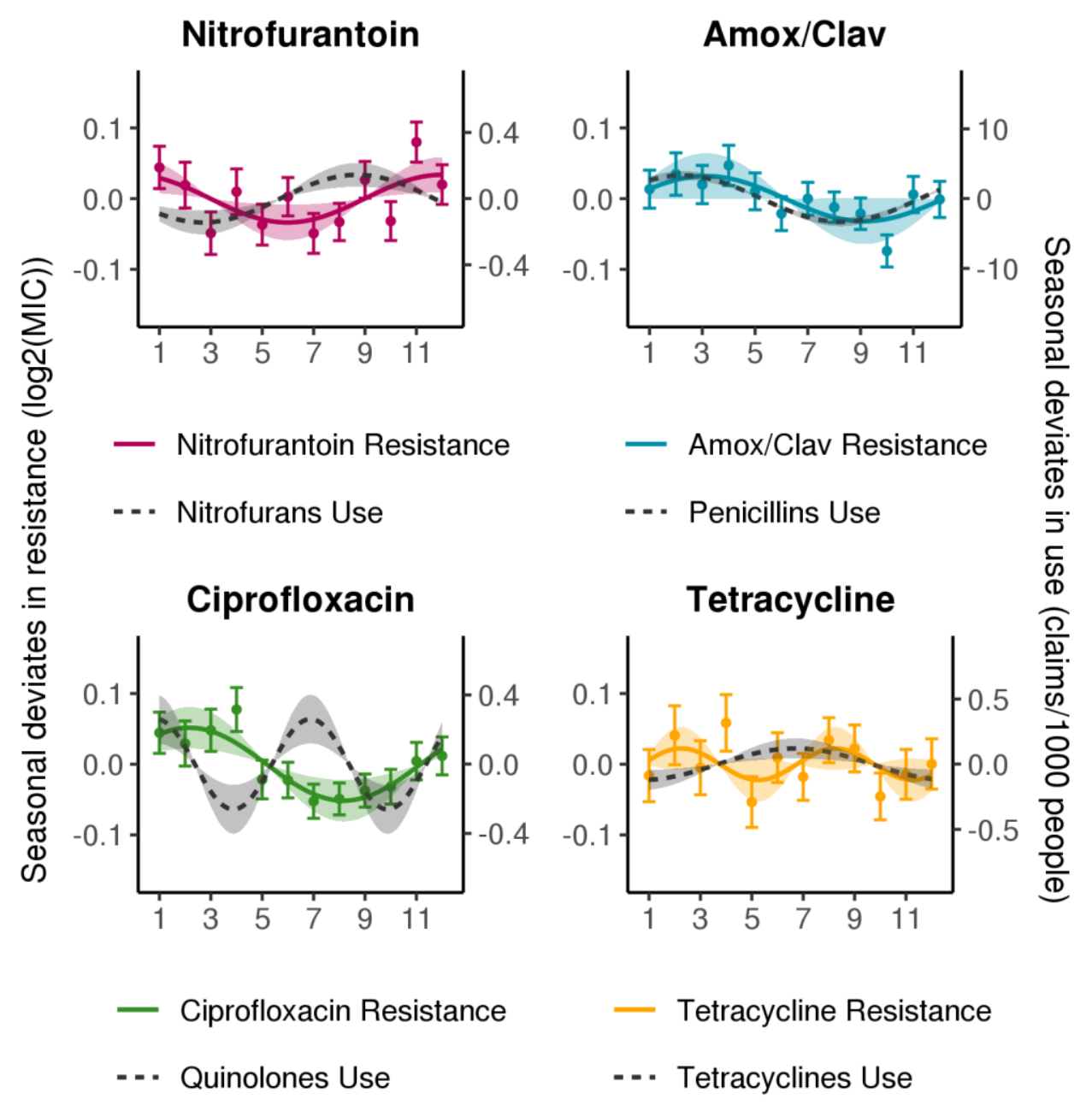

Month

\section{Supplemental Figure 2. Seasonality of antibiotic use and resistance by class in Klebsiella}

pneumoniae. Solid lines indicate point estimates of the amplitude and phase from the best-

522 fitting sinusoidal models of resistance to each antibiotic, colored by class. Dashed grey lines

523 indicate point estimates of the amplitude and phase from sinusoidal models of use of the

524 corresponding antibiotic class. Points indicate the monthly mean seasonal deviates in doubling

525 dilutions and error bars indicate the standard error of the mean. Shaded regions indicate the

$52695 \%$ confidence intervals for the amplitude. Amox/Clav, Amoxicillin-Clavulanate. 

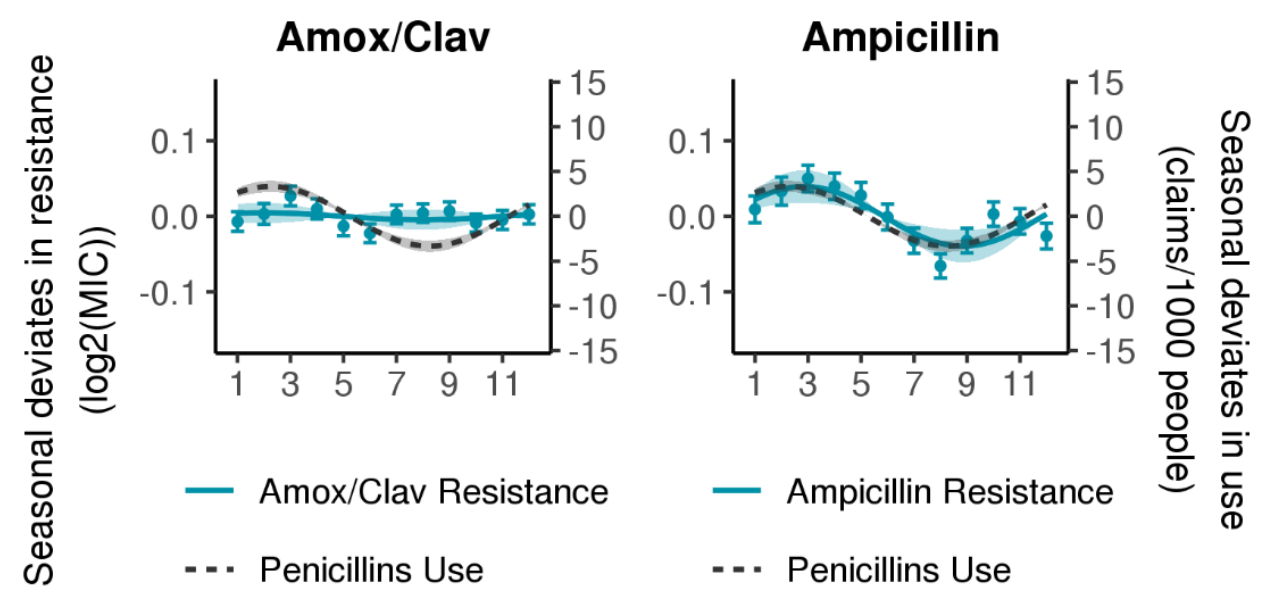

Month

528 Supplemental Figure 3. Seasonality of use and resistance for penicillins in Escherichia

529 coli with a 12-month period model. Solid lines indicate point estimates of the amplitude and

530 phase from 12-month period sinusoidal models of resistance to each antibiotic. Dashed grey

531 lines indicate point estimates of the amplitude and phase from a 12-month period sinusoidal

532 model of use of penicillins class antibiotics. Points indicate the monthly mean seasonal deviates

533 in doubling dilutions and error bars indicate the standard error of the mean. Shaded regions

534 indicate the 95\% confidence intervals for the amplitude. Amox/Clav, Amoxicillin-Clavulanate. 
medRxiv preprint doi: https://doi.org/10.1101/2020.12.21.20248670; this version posted December 22, 2020. The copyright holder for this preprint (which was not certified by peer review) is the author/funder, who has granted medRxiv a license to display the preprint in perpetuity.

It is made available under a CC-BY-NC-ND 4.0 International license .

\begin{tabular}{|c|c|c|c|}
\hline Antibiotic class & Antibiotic name & ATC code & $\begin{array}{l}\text { Percent of total } \\
\text { use within } \\
\text { antibiotic class }\end{array}$ \\
\hline \multirow[t]{8}{*}{ Penicillins } & Amoxicillin & J01CA04 & 82.731 \\
\hline & Phenoxymethylpenicillin & J01CE02 & 15.627 \\
\hline & Dicloxacillin & J01CF01 & 1.14 \\
\hline & Ampicillin & J01CA01 & 0.349 \\
\hline & Benzylpenicillin & J01CE01 & 0.091 \\
\hline & Piperacillin & J01CA12 & 0.036 \\
\hline & Naficillin & J01CF06 & 0.024 \\
\hline & Oxacillin & J01CF04 & 0.003 \\
\hline \multirow[t]{6}{*}{ Macrolides } & Azithromycin & J01FA10 & 51.002 \\
\hline & Clindamycin & J01FF01 & 28.273 \\
\hline & Erythromycin & J01FA01 & 16.948 \\
\hline & Clarithromycin & J01FA09 & 3.775 \\
\hline & Telithromycin & J01FA15 & 0.001 \\
\hline & Lincomycin & J01FF02 & 0.001 \\
\hline \multirow[t]{7}{*}{ Quinolones } & Ciprofloxacin & J01MA02 & 66.561 \\
\hline & Levofloxacin & J01MA12 & 13.512 \\
\hline & Ofloxacin & J01MA01 & 13.311 \\
\hline & Moxifloxacin & J01MA14 & 5.683 \\
\hline & Gatifloxacin & J01MA16 & 0.853 \\
\hline & Norofloxacin & J01MA06 & 0.071 \\
\hline & Gemifloxacin & J01MA15 & 0.01 \\
\hline \multirow[t]{5}{*}{ Tetracyclines } & Doxycycline & J01AA02 & 79.097 \\
\hline & Minocycline & J01AA08 & 18.816 \\
\hline & Tetracycline & J01AA07 & 1.98 \\
\hline & Tigecycline & J01AA12 & 0.054 \\
\hline & Demeclocycline & J01AA01 & 0.053 \\
\hline Nitrofurans & Nitrofurantoin & J01XE01 & 100 \\
\hline
\end{tabular}

Supplemental Table 1. Percent of claims by individual antibiotics within each class.

537 Antibiotic claims data for Boston, MA residents was obtained from the Massachusetts All Payers

538 Claims Database ${ }^{37}$ and subset by antibiotic class according to the following ATC codes $^{40 \text { : }}$

539 penicillins, J01C; macrolides, J01F; quinolones, J01M, tetracyclines, J01A; and nitrofurans,

540 JO1XE. All antibiotics under each ATC header that were present in this dataset were included in

541 the analysis. The percentage of the total claims within each antibiotic class made-up by each

542 individual antibiotic is listed in the last column of the table. 
medRxiv preprint doi: https://doi.org/10.1101/2020.12.21.20248670; this version posted December 22, 2020. The copyright holder for this preprint (which was not certified by peer review) is the author/funder, who has granted medRxiv a license to display the preprint in perpetuity.

It is made available under a CC-BY-NC-ND 4.0 International license .

543

\begin{tabular}{|l|l|l|l|l|}
\hline & & E. coli & K. pneumoniae & S. aureus \\
\hline Total & Total & 131856 & 27245 & 47219 \\
\hline \multirow{3}{*}{ Hospitals } & BWH & $54954(41.7 \%)$ & $11872(43.6 \%)$ & $17649(37.4 \%)$ \\
\cline { 2 - 5 } & MGH & $76902(58.3 \%)$ & $15373(56.4 \%)$ & $29570(62.6 \%)$ \\
\hline \multirow{2}{*}{$\begin{array}{l}\text { Patient } \\
\text { type }\end{array}$} & Inpatient & $22996(17.4 \%)$ & $9403(34.5 \%)$ & $16795(35.6 \%)$ \\
\cline { 2 - 5 } Infection & Outpatient & $108860(82.6 \%)$ & $17842(65.5 \%)$ & $30424(64.4 \%)$ \\
\hline \multirow{5}{*}{ site } & Abscess or fluid NOS & $1942(1.5 \%)$ & $797(2.9 \%)$ & $5128(10.9 \%)$ \\
\cline { 2 - 5 } & Blood & $2587(2 \%)$ & $1396(5.1 \%)$ & $2798(5.9 \%)$ \\
\cline { 2 - 5 } & Respiratory tract & $2619(2 \%)$ & $2823(10.4 \%)$ & $11537(24.4 \%)$ \\
\cline { 2 - 5 } & Skin and soft tissue & $3253(2.5 \%)$ & $1308(4.8 \%)$ & $23753(50.3 \%)$ \\
\cline { 2 - 5 } & Urinary tract & $121455(92.1 \%)$ & $20921(76.8 \%)$ & $4003(8.5 \%)$ \\
\hline \multirow{4}{*}{ group } & $00-19$ & $7633(5.8 \%)$ & $702(2.6 \%)$ & $4444(9.4 \%)$ \\
\cline { 2 - 5 } & $20-39$ & $31344(23.8 \%)$ & $2994(11 \%)$ & $10458(22.1 \%)$ \\
\cline { 2 - 5 } & $40-64$ & $42006(31.9 \%)$ & $8969(32.9 \%)$ & $17243(36.5 \%)$ \\
\cline { 2 - 5 } & $65+$ & $111379(84.5 \%)$ & $18958(69.6 \%)$ & $21486(45.5 \%)$ \\
\hline \multirow{3}{*}{ Gender } & Female & $20477(15.5 \%)$ & $8287(30.4 \%)$ & $25733(54.5 \%)$ \\
\cline { 2 - 5 } & Male & & & \\
\hline
\end{tabular}

544 Supplemental Table 2. Total number of isolates by demographics. Table of the total

545 number of isolates of each species within each clinical or demographic category that we used in

546 our analysis. In parentheses is the percent of the total number of isolates for that species. BWH,

547 Brigham and Women's Hospital; MGH, Massachusetts General Hospital; NOS, not otherwise

548 specified. 
medRxiv preprint doi: https://doi.org/10.1101/2020.12.21.20248670; this version posted December 22, 2020. The copyright holder for this preprint (which was not certified by peer review) is the author/funder, who has granted medRxiv a license to display the preprint in perpetuity.

It is made available under a CC-BY-NC-ND 4.0 International license .

\begin{tabular}{|c|c|c|c|c|c|}
\hline Species & $\begin{array}{l}\text { Antibiotic } \\
\text { (Antibiotic class) }\end{array}$ & $\begin{array}{l}\text { Dates } \\
\text { included at } \\
\text { BWH } \\
\end{array}$ & $\begin{array}{l}\text { Dates } \\
\text { included at } \\
\text { MGH }\end{array}$ & $\begin{array}{l}\text { Percent } \\
\text { resistance } \\
\text { at } \mathrm{BWH}\end{array}$ & $\begin{array}{l}\text { Percent } \\
\text { resistance } \\
\text { at } \mathrm{MGH}\end{array}$ \\
\hline \multirow{5}{*}{ E. coli } & $\begin{array}{l}\text { Amoxicillin/ } \\
\text { Clavulanate } \\
\text { (Penicillins) }\end{array}$ & $\begin{array}{l}\text { May } 2013- \\
\text { Dec } 2019\end{array}$ & $\begin{array}{l}\text { Jan } 2007- \\
\text { Dec } 2016\end{array}$ & 17.5 & 17.2 \\
\hline & $\begin{array}{l}\text { Ampicillin } \\
\text { (Penicillins) }\end{array}$ & \begin{tabular}{|l} 
Jan $2007-$ \\
Dec 2019
\end{tabular} & $\begin{array}{l}\text { Jan } 2007 \text { - } \\
\text { Dec } 2016\end{array}$ & 47.4 & 47 \\
\hline & $\begin{array}{l}\text { Ciprofloxacin } \\
\text { (Quinolones) }\end{array}$ & $\begin{array}{l}\text { Jan } 2007- \\
\text { Dec } 2019 \\
\end{array}$ & $\begin{array}{l}\text { Jan } 2007- \\
\text { Dec } 2016 \\
\end{array}$ & 22.2 & 21.1 \\
\hline & $\begin{array}{l}\text { Nitrofurantoin } \\
\text { (Nitrofurans) }\end{array}$ & \begin{tabular}{|l} 
Jan $2007-$ \\
Jun 2013
\end{tabular} & $\begin{array}{l}\text { Jan } 2007- \\
\text { Dec } 2016 \\
\end{array}$ & 5.9 & 5.1 \\
\hline & $\begin{array}{l}\text { Tetracycline } \\
\text { (Tetracyclines) }\end{array}$ & $\begin{array}{l}\text { May } 2013- \\
\text { Dec } 2019 \\
\end{array}$ & \begin{tabular}{|l|} 
Jan $2007-$ \\
Dec 2016 \\
\end{tabular} & 28.8 & 29.3 \\
\hline \multirow{4}{*}{ K. pneumoniae } & $\begin{array}{l}\text { Amoxicillin/ } \\
\text { Clavulanate } \\
\text { (Penicillins) }\end{array}$ & $\begin{array}{l}\text { May } 2013- \\
\text { Dec } 2019\end{array}$ & $\begin{array}{l}\text { Jan } 2007- \\
\text { Dec } 2016\end{array}$ & 10.1 & 8.2 \\
\hline & $\begin{array}{l}\text { Ciprofloxacin } \\
\text { (Quinolones) }\end{array}$ & \begin{tabular}{|l} 
Jan $2007-$ \\
Dec 2019
\end{tabular} & \begin{tabular}{|l|} 
Jan $2007-$ \\
Dec 2016
\end{tabular} & 11.5 & 11 \\
\hline & $\begin{array}{l}\text { Nitrofurantoin } \\
\text { (Nitrofurans) }\end{array}$ & $\begin{array}{l}\text { Jan } 2007- \\
\text { Jun } 2013\end{array}$ & $\begin{array}{l}\text { Jan } 2007 \text { - } \\
\text { Dec } 2016\end{array}$ & 69.2 & 68.1 \\
\hline & $\begin{array}{l}\text { Tetracycline } \\
\text { (Tetracyclines) }\end{array}$ & $\begin{array}{l}\text { May } 2013- \\
\text { Dec } 2019\end{array}$ & \begin{tabular}{|l} 
Jan $2007-$ \\
Dec 2016 \\
\end{tabular} & 21.1 & 18.3 \\
\hline \multirow{6}{*}{ S. aureus } & $\begin{array}{l}\text { Ciprofloxacin } \\
\text { (Quinolones) }\end{array}$ & $\begin{array}{l}\text { May } 2010- \\
\text { Dec } 2019\end{array}$ & $\begin{array}{l}\text { Jan } 2009- \\
\text { Dec } 2016 \\
\end{array}$ & 29.5 & 30.7 \\
\hline & $\begin{array}{l}\text { Erythromycin } \\
\text { (Macrolides) }\end{array}$ & $\begin{array}{l}\text { May } 2010- \\
\text { Dec } 2019 \\
\end{array}$ & \begin{tabular}{|l|} 
Jan $2009-$ \\
Dec 2016 \\
\end{tabular} & 51.1 & 54.9 \\
\hline & $\begin{array}{l}\text { Nitrofurantoin } \\
\text { (Nitrofurans) }\end{array}$ & $\begin{array}{l}\text { May } 2010- \\
\text { Jun } 2013\end{array}$ & $\begin{array}{l}\text { Jan } 2009- \\
\text { Dec } 2016\end{array}$ & 1.1 & 1 \\
\hline & $\begin{array}{l}\text { Oxacillin } \\
\text { (Penicillins) }\end{array}$ & $\begin{array}{l}\text { May } 2010- \\
\text { Dec } 2019\end{array}$ & \begin{tabular}{|l} 
Jan $2009-$ \\
Dec 2016 \\
\end{tabular} & 29.8 & 35.9 \\
\hline & $\begin{array}{l}\text { Penicillin } \\
\text { (Penicillins) }\end{array}$ & $\begin{array}{l}\text { May } 2010- \\
\text { Dec } 2019\end{array}$ & $\begin{array}{l}\text { Jan } 2009- \\
\text { Apr } 2015\end{array}$ & 81.5 & 84.3 \\
\hline & $\begin{array}{l}\text { Tetracycline } \\
\text { (Tetracyclines) }\end{array}$ & $\begin{array}{l}\text { May } 2010- \\
\text { Dec } 2019\end{array}$ & $\begin{array}{l}\text { Jan } 2009- \\
\text { Dec } 2016 \\
\end{array}$ & 6.5 & 6 \\
\hline
\end{tabular}

Supplemental Table 3. Antibiotics included in analysis and percent resistance by

hospital. Resistance was determined by applying 2017 CLSI breakpoints to the reported

552 minimum inhibitory concentration (MIC) values for each isolate; isolates categorized as

553 intermediate resistance were considered resistant. Percent resistance was calculated as the

554 percentage of resistant isolates out of the total number of isolates from each hospital with a

555 reported MIC value for that antibiotic. BWH, Brigham and Women's Hospital; MGH,

556 Massachusetts General Hospital. 


\begin{tabular}{|l|l|l|}
\hline \multirow{2}{*}{ Antibiotic Class } & \multicolumn{2}{|c|}{ Antibiotic Use Regression Model } \\
\cline { 2 - 3 } & 12-month period & 6-month period \\
\hline Macrolides & $183.3(+0)$ & $232.4(+49.1)$ \\
\hline Nitrofurans & $-64.8(+0)$ & $-52(+12.8)$ \\
\hline Penicillins & $191.4(+0)$ & $255.9(+64.5)$ \\
\hline Quinolones & $67.9(+4.4)$ & $63.5(+0)$ \\
\hline Tetracyclines & $-12.1(+0)$ & $-5.9(+6.2)$ \\
\hline
\end{tabular}

\section{Supplemental Table 4. Comparison of the Akaike information criterion (AIC) values}

\begin{tabular}{|l|l|l|l|}
\hline \multirow{3}{*}{ Species } & Antibiotic & \multicolumn{2}{|l|}{ Antibiotic Resistance Regression Model } \\
\cline { 2 - 4 } & & 12-month period & 6-month period \\
\hline \multirow{5}{*}{ E. coli } & Amoxicillin/Clavulanate & $343849.1(+4.2)$ & $343844.9(+0)$ \\
\cline { 2 - 4 } & Ampicillin & $526712.7(+5)$ & $526707.7(+0)$ \\
\cline { 2 - 4 } & Ciprofloxacin & $503167.1(+0)$ & $503174(+6.9)$ \\
\cline { 2 - 4 } & Nitrofurantoin & $199216.1(+0)$ & $199237.5(+21.3)$ \\
\cline { 2 - 4 } & Tetracycline & $427780.6(+0.5)$ & $427780.1(+0)$ \\
\hline \multirow{5}{*}{ S. pneumoniae aureus } & Amoxicillin/Clavulanate & $65272.4(+0)$ & $65275.9(+3.6)$ \\
\cline { 2 - 4 } & Ciprofloxacin & $89763.1(+0)$ & $89774.1(+11)$ \\
\cline { 2 - 4 } & Nitrofurantoin & $66283(+0)$ & $66289.3(+6.3)$ \\
\cline { 2 - 4 } & Tetracycline & $80847.4(+2)$ & $80845.4(+0)$ \\
\hline & Ciprofloxacin & $188999.8(+0)$ & $189021.3(+21.5)$ \\
\cline { 2 - 4 } & Erythromycin & $215665.6(+0)$ & $215671.3(+5.7)$ \\
\cline { 2 - 4 } & Nitrofurantoin & $52311.1(+0)$ & $132327.2(+16.1)$ \\
\cline { 2 - 4 } & Oxacillin & $182474.7(+0)$ & $132482.9(+8.2)$ \\
\cline { 2 - 4 } & Penicillin & $125065.1(+0)$ & $1306.4(+0.3)$ \\
\cline { 2 - 4 } & Tetracycline & $131306(+0)$ & $(+1.7)$ \\
\hline
\end{tabular}

AIC from the model with the lower AIC. 